\title{
PENCULIKAN ANAK OLEH ORANG TUA (STUDI KASUS DI PENGADILAN NEGERI GIANYAR)
}

\author{
I Komang Oka Raharja, A. A. Sagung Laksmi Dewi, Luh Putu Suryani \\ Fakultas Hukum Universitas Warmadewa, Denpasar - Bali, Indonesia
}

\begin{abstract}
Abstrak
Anak yang terlantar harus diberikan perlindungan dari lembaga ataupun Undang-Undang yang bertujuan untuk melindungi hak anak. Anak teah sering menjadi korban tindakan kejahatan, yang salah satunya ialah penculikan. Terkait dengan penculikan anak, Undang-Undang Nomor 35 Tahun 2014 tentang Perlindungan Anak menetapkan bahwa peristiwa penculikan dan terlantar anak oleh orang tua bisa mengakibatkan gangguan fisik dan psikis bagi anak telantar serta tak terpenuhinya hak-hak mereka. Oleh karena itu, perlu adanya sanksi pidana yang dijatuhkan kepada orang tua atau orang lain yang menerlantarkan anak-anak. Berdasarkan hal tersebut, rumusan masalah penelitian ini adalah: Bagaimanakah pengaturan perlindungan hukum kepada anak-anak dari tindakan penculikan yang dilakukan oleh orang tua? Apa sanksi hukum terhadap orang tua yang melakukan penculikan anak. Metode penelitian yang digunakan dalam penelitian ini adalah yuridis normatif, dengan menggunakan pendekatan perundang-undangan, konseptual, dan kasus. Data dianalisis dengan mempergunakan metode kualitatif-normatif. Berdasarkan hasil analisis data, pengaturan perlindungan hukum bagi anak dari tindakan penculikan yang dilakukan oleh orang tua ialah bahwa orang tua harus menjamin terpenuhinya hak-hak anak agar dapat hidup, tumbuh dan berkembang serta berpartisipasi secara optimal sesuai dengan harkat dan martabat kemanusiaan, serta mendapat perlindungan dari kekerasan dan diskrimisasi demi terwujudnya anak Indonesia yang berkualitas, berakhlak mulia dan sejahtera. Sanksi hukum terhadap orang tua yang menculik anaknya diatur dalam pasal 330 ayat (1) KUHP jo. Pasal 55 ayat (1) ke 1 KUHP. Dengan memperhatikan Pasal 330 ayat (2) KUHP Jo. Pasal 55 ayat (1) ke 1 KUHP dan Undang Undang Nomor 8 Tahun 1981 tentang Hukum Acara Pidana serta peraturan perundang-undangan yang berlaku.
\end{abstract}

Kata Kunci: Penculikan Anak oleh Orang Tua; Perlindungan Hukum terhadap Anak; Sanksi Hukum

\begin{abstract}
Every neglected children must be given protection from institutions or laws which aims at protecting their rights. Children have often been victims of crimes, one of which is kidnapping. Regarding the kidnapping of children, Law Number 35 of 2014 concerning Child Protection stipulates that the incidents of kidnapping and neglected children by parents can cause physical and psychological harms to those neglected children and the unfulfillment of their rights. Therefore, it is necessary to impose criminal sanctions on parents or other people who neglect children. Grounded by this, the problems examined in the present research are: How is the legal protection for children from kidnapping by parents regulated? What are the legal sanctions against parents who commit kidnapping over their children? The research method used in this research is normative juridical, with statutory, conceptual, and case approaches. Data were analysed using a qualitative-normative method. Based on the results of data analysis, the regulation of legal protection for children from kidnapping committed by parents is that every parent shall ensure the fulfillment of children's rights so that they can live, grow and develop and participate optimally in accordance with human dignity, so that they receive protection from violence and discrimination for the sake of the realisation of Indonesian children who are qualified, noble and prosperous. The legal sanctions against parents kidnapping their children are regulated in Article 330 paragraph (1) of the Criminal Code jo. Article 55 paragraph (1) to 1 KUHP with due observance of Article 330 paragraph (2) KUHP jo. Article 55 paragraph (1) to 1 of the Criminal Code and Law Number 8 of 1981 concerning Criminal Procedure Law and applicable laws and regulations.
\end{abstract}

Keywords: Kidnapping committed by parents, Legal protection for children, Legal sanction 


\section{PENDAHULUAN}

Negara adalah bagian dari institusi yang terbesar memiliki fungsi yang besar dalam mewujudkan tatanan sistem yang dibangunnya agar berjalan maksimal. Dalam hal ini secara umum adanya tujuan negara merupakan landasan dasar terbentuknya negara. Baik maupun buruk, tentunya tujuan negara tersebut menjadikan dasar negara itu ada dan terbentuk (Suhardin, 2012). Pasal 1 ayat (3) UUD 1945 amandemen ke empat secara tegas menyatakan Negara Indonesia merupakan negara Hukum. Pernyataan tersebut berlandaskan konstitusi dimana Indonesia merupakan negaara yang berdiri berdasarkan landasan hukum, di mana hukum dijadikan aturan atau pedoman dalam menjalani hidup dan di masyarakat, bangsa, negara. Dengan adanya hukum ruang gerak kita sebagai masyarakat menjadi terbatas, sehingga tidak dapat bertindak seenaknya terlebih lagi untuk melakukan suatu kejahatan seperti mermpas kebebasan orang lain dengan cara penculikan.

Anak sering menjadi objek dalam penculikan yang dilakukan oleh orang tua kandungnya yang sudah sah bercerai hal tersebut dikarenakan terdapat kelemahan fisik oleh anak. Kejahatan kepada anak seperti penculikan dilakukan oleh ibu kandungnya sendiri yang sudah bercerai (Sudrajat, 2011). Keadaan yang seperti ini keadaan seperti tersebut tidak saja terjadi di Indonesia namun hampir di seluruh di dunia ini. Walaupun saat ini anak dilindungi oleh UU akan tetapi pada kenyataannya belum bisa menujukkan hasil signifikan. Dengan demikian, siapapun dilarang menempatkan, membiarkan, melakukan, menyuruh melakukan, atau turut serta melakukan penculikan sebagaimana dimaksud. Walaupun pemerintah sudah membuat UU tentang perlindungan anak, serta menjamin Hak Asasi Anak, akan tetapi secara realita tindak kejahatan kepada hak anak masih sering terjadi. Kejahatan terhadap HAM anak tidak tentang eksplotasi anak tetapi meliputi juga kejahatan lain pada anak. Contohnya kejahatan penculikan anak yang sering terjadi yang dijadikan korban pada saat ini. Kasus penculikan terhadap anak kembali mengundang perihatin kepada keluarga, masyarakat, serta bertambah urutan kasus penculikan anak di Indonesia. Yang menjadi perhatian ialah anak menjadi korban penculikan, seksual, serta pekerjakan secara serta ada juga yang sampai di dagangkan ke luar negerl. Adapun yang menjadi perhatian cukup besar dan peran besar dalam perkara penculikan anak ialah pelaku kejahatan tersebut. Dengan demikian kajian kajian secara kriminologis jurnal ini memiliki tujuan untuk membuka pola pikir tentang perkara penculikan anak yang dilakukan oleh orang tuanya sendiri.

Berdasarkan uraian di atas, maka tujuan dari penelitian ini adalah untuk mengetahui pengaturan perlindungan hukum oleh orang tua terhadap anak, dan untuk mengetahui sanksi hukum terhadap orang tua yang menculik anaknya.

\section{METODE PENELITIAN}

Metode yang dipergunakan dalam penelitian ini adalah penelitian normatif. Penelitian hukum normatif yaitu penelitian hukum yang meninjau hukum tertulis dari bermacam aspek yaitu aspek sejarah filosofi, teori, perbandingan, lingkup, komposisi, struktur, konsistensi, materi, formalitas, penjelasan umum dan pasaI demi pasaI, kekuatan yang mengikat dalam suatu UU, dan bahasa hukum yang dipergunakan (Muhamad, 2004). Dalam penelitian ini, penyusunan yang dipergunakan adalah dari bahan hukum yang digali dari penelitian kepustakaan berupa: Bahan hukum primer, yaitu unsur utama dari penelitian ini (Soekanto \& Mamudji, 2006). Bahan hukum tersebut terdiri atas peraturan perundang perundang-perundangan, catatan resmi maupun dan putusan Pengadilan. Bahan hukum sekunder yang digunakan adalah buku-buku, kamus-kamus, hasil penelitian ahli hukum, jurnal-jurnal hukum mengenai hukum pidana tentang penculikan anak, dan website-website yang menelaah tentang tindak pidana penculikan.

Pengumpulan bahan hukum dengan melakukan penelitian dengan memakai teknik pengumpulan bahan dengan cara mempelajari bahan-bahan hukum primer dan sekunder yang ada (Soekanto, 2007). Baik berupa peraturan perundang-undangan maupun buku-buku dan literatur-literatur. Pertama-tama dilakukan invintarisasi terhadap bahan hukum primer dan sekunder kemudian diklasifikasi dan selanjutnya dipilih bahan hukum yang sesuai dengan kebutuhan penulis mengenai Penculikan anak oleh orang tua. Dalam penelitian ini, setelah semua bahan-bahan hukum terkumpul, kemudian dianalisis dan disusun secara sistematis dengan menggunakan Argumentasi hukum secara deduktif yaitu penerapan norma kedalam kasus-kasus dan induktif analitik yaitu kasus digeneralisir untuk menjadi norma-norma. Dengan demikian dapat diketahui lebih jelas bahan hukum yang dianalisis sudah sesuai dengan yang dibahas. 


\section{HASIL DAN PEMBAHASAN}

\section{Pengaturan Perlindungan Hukum oleh Orang Tua terhadap Anak}

Perlindungan menurut KBBl berarti tempat berlindung maupun menempatkan perbuatan (haI meIindungi, seperti member lindungan terhadap seseorang yang lemah) (Bahasa, 1990). Perlindungan hukum ialah peraturan maupun kaidah yang mempunyai isi dan bersifat umum serta normatif, umum karena berlaku kepada semua orang dan normative karena menentukan seperti apa caranya meIaksanakan kepatuhan pada kaidah-kaidah tersebut. Perlindungan hukum merupakan suatu tindakan dalam haI untuk melindungi subyek-subyek hukum menggunakan Undang Undang yang berlaku serta pelaksanaanya bisa secara paksakan dengan suatu sanksi. Dalam hal ini adalah agar hakhak anak dilindungi secara hukum maupun orang tua. Anak ialah amanat dan karunia Tuhan Yang Maha Esa yang wajib dilindungi dan dijaga karena pada anak juga melekat hak-hak harkayt, dan martabat sebagai bagian dari manusia yang harus dijunjung tinggi. Faktanya keadaan anak di Indonesia masih belum menggembirakan nasib mereka belum seindah ungkapan verbal yang sering diposisikan sebagai sesuatu yang anak penting bernilai, serta sebagai penerus bangsa dan Negara. Anak sangat rentan menjadi korban didalam suatu tindak kejahatan.

Dalam UU Tentang Sistem Peradilan Pidana Anak menyatakan bahwa pertanggung jawaban orang tua, keIuarga, masyarakat, pemerintah serta negara merupakan rangkaian pelaksanaan yang harus dilaksanakan secara terus menerus agar terlindungnya hak anak. Kegiatan perlindungan anak perlu dilakukan secepat mungkin, yaitu malai dari dalam janin daIam kandungan sampai sang anak berusia deIapan beIas tahun. Berdasarkan dari konsep perlindungan anak yang utuh, komprehensif serta menyeluruh, dalam UURI Tentang Sisitem Peradilan Pidana Anak tersebut memberikan kewajiban perlindungan kepada anak berdasarkan asas sebagai berikut,

1. Nondiskeiminasi,

2. Kepentingan bagi anak yang terbaik,

3. Kelangsungan hidup, hak untuk hidup, penghargaan terhadap pendapay anak, perkembangan.

Pengaturan perllindungan hokum oleh orang tua terhadap anak pada prinsipnya adalah orang tua harus melindungi anak agar terpenuhinya hak dan kewajibannya dari ancaman dalam maupun luar dirinya, dengan cara membina, mendidik, mendampingi anak, mengusahakan kesehatannya mencegah anak kelaparan, menyediakan sarana dan prasarana untuk mengembangkan diri serta yang lainnya. Perlindungan terhadap anak bermanfaat untuk anak orang tua dan pemerintah, maka koordinasi dan kerjasama perlindungan terhadap anak perlu dilaksanakan untuk mengatasi ketidakseimbangan kegiatan perlindungan terhadap anak secara keseluruhan. Tindak Pidana penculikan anak oleh orang tua ialah suatu tindakan menyimpang, bertentangan dengan hukum atau melanggar UU yang diatur dalam hukum pidana dan merugikan masyarakat baik dipandang dari segi kesuisilaan, kesopanan, dan ketertiban anggota masyarakat.

Akibat hukum ialah suatu akibat yang ditimbulkan dari peristiwa hokum (Ishaq, 2008). Adanya perbuatan hukum disebabkan dari peristiwa hukum, suatu perbuatan hukum dapat menimbulkan hubungan hukum, dengan demikian akibat hukum juga bisa dimaknai sebagai akibat yang ditimbulkan dari adanya hubungan hukum atau perbuatan hukum. Seperti contoh kasus orang tua menculik anaknya yang tidak memiliki hak asuh anak, yang terjadi di Pengadilan Negeri Gianyar, yaitu: Berdasarkan fakta-fakta yang terungkap di persidangan dengan Terdakwa (I) Ni Putu Nia Riani pada hari Senin Tanggal 4 Desember 2017 sekitar jam 07.30 Wita, atau setidak-tidaknya pada bulan Desember 2017 atau setidak-tidaknya pada tahun 2017, bertempat di Jalan Raya Katiklantang, Banjar Katiklantang, Desa Singakerta, Kecamatan Ubud, Kabupaten Gianyar atau setidak-tidaknya pada tempat tertentu yang masih termasuk dalam Daerah Hukum Pengadilan Negeri Gianyar, telah menempatkan, membiakan, melakukan, menyuruh melakukan, atau turut serta melakukan penculikan, penjualan, dan/atau perdagangan anak, yang para terdakwa dengan cara-cara sebagai berikut.

Pada hari Kamis tanggal 23 Nopember 2017 sekira jam 13.00 Wita Terdakwa (I) Ni Putu Nia Riani menelpon terdakwa (II) I Putu Agus Arya Kesuma mereka janjian untuk bertemu meminta bantuan kepada Terdakwa (II) I Putu Agus Arya Kesuma dan mengajak beberapa orang temannya, untuk mendampingi mengambil anak-anaknya dari mantan suaminya yaitu Saksi Made Putra Diana. Terdakwa Ni Putu Nia Riani akan memberikan upah kepada terdakwa (II) I Putu Agus Arya Kesuma yang nominalnya belum ditentukan saat itu. Pada tanggal 4 Desember 2017 sekitar pukul 06.00 Wita Terdakwa (I) Ni Putu Nia Riana berkumpul dengan terdakwa (II) I Putu Agus Arya Kesuma dan 
dikuti oleh terdakwa (III) I G. N. Bayu Suta Negara, terdakwa (IV) IWayan Putra Wijaya, terdakwa (V) Made Tantra Purnama, terdakawa (VI) Made Arista Prawira. Melihat anak-anaknya diantar kesekolah oleh ayahnya, terdakwa (I) Ni Putu Nia Riani mengambil anak-anaknya dan membawa masuk ke dalam mobil, setelah mereka di dalam mobil saksi I Made Putra Diana tetap berusaha mengambil kembali anak-anaknya dari dalam mobil dengan cara menarik anaknya yang perempuan yaitu Ni Putu Thania Leonytha Gavrila Diana tetapi dengan pegangan saksi I Made Putra Diana dilepaskan oleh terdakwa (II) I Putu Agus Arya Kesuma sehingga pintu mobil berhasil di tutup oleh terdakwa (I) Ni Putu Nia Riana.

Terdakwa (I) Ni Putu Nia Riana melakukannya karena selalu di halang-halangi saat mau bertemu dengan anak. Terdakwa (I) Ni Putu Nia Riana mengajak teman-teman adalah tujuannya untuk mengamankan karena kalau mengambil sendiri maka akan bertengkar. Mengamankan disini maksudnya apabila sesuatu terjadi pada Terdakwa I maka mereka akan melindungi Terdakwa I. Akibat perbuatan terdakwa, Ni Putu Thania Leonytha Gavrila Diana dan I Made Rama Divyanand Putra Diana mengalami Post Traumatic Stress Disorder dengan anxietas (kecemasan) sesuai dengan Hasil Pemeriksaan Psikiater di. A.A.A. Indriany, SP.Kj. Nomor : 01/P2TP2A-Gianya///2018 tanggal 16 Januari 2018 dan saksi I Made Putra Diana mengalami luka memar pada pertengahan lengan atas, luka lecet pada ketiga jari bagian bawah, luka memar pada pergelangan tangan kiri sebagaimana Visum Et Repertum Nomor : 1704/RSAC/XII/2017 tanggal 13 Desember 2017 yang ditandatangani oleh dr. I Putu Indra Yudha, M.P yang hasil pemeriksaan yaitu:

Pemeriksaan Luar:

Leher: Kemerahan pada leher kanan;

Lengan kanan atas: Luka memar pada pertengahan lengan atas ukuran empat kali tiga centimeter;

Tangan Kanan: Luka lecet pada jari ketiga bagian bawah ukuran satu kali satu centimeter;

Pergelangan lengan kiri: Luka memar pada pergelangan tangan kiri;

Lutut kanan: Luka lecet ukuran satu kali satu centimeter;

Kesimpulan: Keadaan tersebut diakibatkan oleh benturan dengan benda tumpul.

\section{Sanksi Hukum Terhadap Orang Tua Yang Menculik Anaknya}

Sanksi Pidana yaitu suatu sanksi yang ditimbulkan dari sebab dan akibat, sebab ialah kasusnya serta akibat hukumnya, seseorang yang terkena kasus akan mendapatkan sanksi baik penjara maupun kena hukuman yang lain dari pihak berwenang (Hamzah, 2008). Sanksi Pidana ialah suatu sanksi yang bersifat tegas yang diancamkan maupun dikenakan terhadap perbuatan atau pelaku tindak pidana yang membahayakan maupun mengganggu kepentingan hukum. Sanksi pidana intinya merupakan suatu penjamin untuk merehabilitasi pelaku dari perilaku tindak pidana. Sanksi pidana terhadap orang tua yang menculik anaknya yang tidak menjadi hak asuh anak tersebut diatur serta diancam pidana daIam Passal 330 Ayat (1) KUHP Jo. Pasal 55 Ayat (1) ke 1 KUHP Jo. Pasal 55 ayat (1) ke 1 KUHP, yang unsur-unsurnya adalah,

a. Unsur Barang Siapa

Yang dimaksud dengan Barang Siapa yaitu menunjuk kepada orang perseorangan selaku subyek hukum yang perbuatannya dapat dipertanggungjawabkan secara hukum. Dalam unsur Barang Siapa selain menunjukan kepada siapa orang yang harus bertanggung jawab atas perbuatan atau kejadian yang didakwakan juga menunjukan bahwa orang yang dijadikan Terdakwa harus sehat secara jasmani dan rohani sehingga dapat mempertanggungjawabkan perbuatannya.

b. Unsur Dengan Sengaja Menarik Seseorang Yang Belum Cukup Umur dari Kekuasaan yang Menurut Undang Undang Ditentukan Atas Dirinya, atau dari Pengawasan Orang yang Berwenang untuk Itu.

Sengaja adalah Para Terdakwa dalam melakukan perbuatannya harus mengehendaki perbuatan tersebut serta mengerti dan menghendaki akibat yang akan dihasilkan dari perbuatan yang dilakukannya tersebut.

c. Unsur Dilakukan dengan Tipu Muslihat, Kekerasan, atau Ancaman Kekerasan, atau Bilamana Anaknya Belum Berumur 12 (dua belas) tahun.

Yang dimaksud dengan unsur Dilakukan dengan Tipu Muslihat, Kekerasan, atau Ancaman Kekerasan, atau Bilamana Anaknya Belum Berumur dua belas tahun adalah orang yang dengan sengaja menarik (merebut atau melarikan) orang yang belum dewasa serta kekerasan dari kekuasaan orang yang berhak, yaitu pemegang hak asuh anak. 
d. Unsur Baik sebagai Yang Melakukan, Menyuruh Melakukan atau Turut Serta Melakukan

Bahwa unsur dalam pasal ini menggunakan kata atau dalam perumusan delik, yang mempunyai arti bahwa unsur ini dirumuskan secara alternatif yaitu apabila salah satu dari unsur pasal ini telah terpenuhi oleh Terdakwa, maka Terdakwa dianggap telah terbukti melakukan delik yang dimaksud. Unsur telah melakukan atau turut serta melakukan yang dimaksud di dalam rumusan Pasil 55 ayat (1) ke-1 KUHPidana ialah mereka yang bersama sama melakukan perbuatan pidana atau dengan kata lain mereka yang dengan sengaja ikut mengerjakan suatu perbuatan.

Maksud dari pemidanaan yaitu untuk mencegah tindak kejahatan yang akan dilakukannya pada suatu hari nanti, tujuan diadakannya pemidanaan diperlukan untuk mengetahui sifat dasar hukum dari pidana. Sehingga tujuan pemidanaan bukanlah sebagai pembalasan akan perbuatan pidana yang dilakukan oleh Para Terdakwa, tetapi sebagai upaya mendidik dan memperbaiki sehingga Para Terdakwa di kemudian hari dapat menjadi manusia yang lebih baik serta pemidanaan ini sebagai upaya mencegah agar Para Terdakwa atau orang lain tidak melakukan perbuatan sebagaimana yang telah dilakukan oleh Para Terdakwa dalam kasus ini.

\section{SIMPULAN DAN SARAN Simpulan}

Berdasarkan pembahasan diatas dapat disimpulkan: 1) Pengaturan perlindungan hokum oleh orang tua terhadap anak pada intinya ialah orang tua harus melindungi hal anak sehingga anak dapat melaksanakan hak maupun kewajibannya dari ancaman dalam maupun luar dirinya, dengan cara membina, mendidik, mengusahakan kesehatannya, mencegah anak kelaparan, mendampingi anak, menyediakan sarana dan prasarana untuk pengembangan diri dan sebagainya, yang diatur UU Perlindugan Anak. 2) Sanlsi hukum terhadap orang tua yang Meculik anaknya: seperti contoh kasus di Pengadilan Negeri Gianyar nomor perkara Nomor 29/Pid.Sus/2018/PN Gin adalah Bahwa Para Terdakwa telah didakwa oleh Penuntut Umum dengan dakwaan yang berbentuk alternatif, sehingga Majelis Hakim dengan memperhatikan faktafakta hukum tersebut diatas memilih langsung dakwaan alternatif ke kedua sebagaimana diatur dalam Pasal 330 ayat (1) KUHP Jo. Pasal 55 ayat (1) ke 1 KUHP, dengan mempertimbangkan unsurunsurnya, dan mempertimbangkan keadaan yang memberatkan dan meringankan Para Terdakwa. Menjatuhkan pidana kepada Para Terdakwa oleh karena itu dengan pidana penjara masing masing selama 8 (delapan) bulan.

\section{Saran}

Dari pembahasan tersebut disampaikan: 1) Orang tua harus menjamin terpenuhinya hak-hak anak agar dapat hidup, tumbuh berkembang dan berpartisipasi secara optimal sesuai dengan harkat dan martabat kemanusiaan, serta mendapat perlindungan dari kekerasan dan diskrimisasi yang dapat menyebabkan anak tesebut menjadi trauma, demi terwujudnya anak Indonesia yang berkualitas, berakhlak mulia dan sejahtera. 2) Seharusnya orang tua yang tidak menjadi hak asuh anak tersebut apabila anak itu diambil dengan baik-baik dan kemudian ditempatkan disuatu tempat tanpa suatu persoalan maka tidak dapat ikategorikan penculikan.

\section{DAFTAR PUSTAKA}

Bahasa, T. penyusun K. P. P. dan P. (1990). Kamus Besar Bahasa Indonesia. Jakarta: Balai Pustaka. Hamzah, A. (2008). Asas-asas Hukum Pidana. Jakarta: Rineka Cipta.

Ishaq. (2008). Dasar-Dasar Ilmu Hukum. Jakarta: Sinar Grafika.

Muhamad, A. (2004). Hukum dan Penelitian Hukum. Jakarta: PT. Citra Aditya Bakti.

Soekanto, S. (2007). Pengantar Penelitian Hukum. Jakarta: UI Pers.

Soekanto, S., \& Mamudji, S. (2006). Penelitian Hukum Normatif Tinjauan Singkat. Jakarta: Rajawali Pers.

Sudrajat, T. (2011). Perlindungan Hukum terhadap Hak Anak sebagai Hak Asasi Manusia dalam Perspektif Sistem Hukum Keluarga di Indonesia. Kanun: Jurnal Ilmu Hukum, 13(54), 111-132.

Suhardin, Y. (2012). Peranan Negara dan Hukum dalam Memberantas Kemiskinan dengan Mewujudkan Kesejahteraan Umum. Jurnal Hukum Dan Pembangunan, 42(3).

Undang-Undang Dasar Negara Republik Indonesia Tahun 1945;

Kitab Undang-Undang Hukum Pidana;

Undang-Undang Nomor 39 Tahun 1999 tentang Hak Asasi Manusia (HAM);

Undang - Undang Republik Indnesia Nomor 35 Tahun 2014 Tentang Perubahan Atas Undang - Undang Nomor 23 Tahun 2002 Tentang Perlindungan Anak 